\title{
BuzZ as an Urban Resource ${ }^{1}$
}

\author{
DANiel SiLVer \\ Terry Nichols Clark
}

Abstract. The global rise of arts and culture is transforming local politics. Though new to many academic urban analysts, this is a commonplace for many mayors and local policy makers around the world. We seek to overcome this divide by joining culture and the arts with classic concepts of urban politics. We offer an analytical framework incorporating the politics of cultural policy alongside the typical political economic concerns in the urban politics and development literatures. Our framework synthesizes several research streams that combine in global factors driving the articulation of culture into city politics. This frames our studies of the local processes through which this articulation occurs on the ground in Toronto.

Key words: urban politics, politics of arts and culture, new political culture, resources, new social movements

Résumé. La montée mondiale des arts et la culture transforme la politique locale. Bien que nouvelle a de nombreux analystes universitaires, c'est une monnaie courante pour de nombreux maires et décideurs dans le monde entier. Nous cherchons à combler ce fossé en ajoutant la culture et les arts aux concepts classiques de la politique urbaine. Nous offrons un cadre analytique intégrant la politique de la politique culturelle aux côtés des typiques préoccupations économiques politiques dans la politique urbaine et les littératures de développement. Notre cadre synthèse plusieurs axes de recherche qui combine les facteurs mondiaux au volant de l'articulation de la culture dans la politique de la ville. Cela encadre nos études sur les processus à travers lesquelles cette articulation se produit sur le terrain à Toronto.

Mots clés: politique urbaine, politique des arts et culture, nouvelle culture politique, resources, mouvements sociaux nouvelles

1. We thank for their helpful comments Herman Boschken, Meghan Kallman, Sarah Cappeliez, Stephen Sawyer, and two anonymous CJS reviewers. Sarah Cappeliez and Nicholas Musillami provided valuable research assistance. This research was supported by the Social Sciences and Humanities Research Council. 
In the concluding paragraphs of The Economy of Cities, Jane Jacobs left her readers with a fanciful piece of science fiction on what she considered "one of the most pressing and least regarded" problems facing cities.

I am not one who believes that flying saucers carry creatures from other solar systems who poke curiously into our earthly affairs. But if such beings were to arrive, with their marvelously advanced contrivances, we may be sure we would be agog to learn how their technology worked. The important question, however, would be something quite different: What kinds of governments had they invented which had succeeded in keeping open the opportunities for economic and technological development instead of closing them off? Without helpful advice from outer space, this remains one of the most pressing and least regarded problems. (Jacobs 1970:235)

Jacobs' book barely touches on politics. Instead, she focuses on urban economics, arguing that (1) development in general is driven by cities more than the countryside and (2) urban development is driven by innovation more than efficiency. She elaborates these points in rich and detailed ways that have been popularized and expanded by her followers such as Edward Glaeser and Richard Florida. But she could not even begin to imagine the potential forms of urban politics that would foster what would later be called "creative cities." Such governments in her mind could only be the stuff of science fiction.

Writing in 1968, Jacobs can be excused for this failure of imagination. Contemporary urban theorists - followers of Jacobs, but not only them - cannot. The social world has changed since 1968. Citizens participate more in the arts, culture, and creative activities of all sorts in recent years. Increases are higher for middle and low status persons, especially in the United States, Canada, and Northern Europe, detailed below. "The Creative City" features high on political agendas of cities worldwide. Political leaders and styles of urban government have in some cities dramatically changed, adding culture and innovation to their past repertoires. How can we analyze and interpret these new developments? What kinds of governments and forms of political power do they involve?

We suggest some theoretical tools to add arts and culture to the study of urban politics. Our primary contributions in this paper are conceptual, synthetic, and analytical. Many of our points are not new per se. We bring them together into a single picture and seek to join them with traditional models where the arts and culture barely register.

We first outline key global factors driving the "rise of arts culture" into city politics and discuss how these are mediated by local context. 
The global factors we identify synthesize research in urban sociology, urban politics, and urban economics. The local processes we discuss highlight the "bearers" of these global factors. We then develop a theoretical framework for interpreting city politics in the wake of these changes. We build on classic approaches in urban politics (e.g., Dahl, Peterson) stressing the plurality of resources that can be brought to bear on political decisions in different ways depending on the issue area. Drawing on the notion of "symbolic media of exchange" from Talcott Parsons and Jeffrey Alexander, we propose treating "buzz" as a valuable symbolic resource generated by urban cultural scenes. This is a resource, we suggest, that can be wielded, in certain situations and issue areas, to influence political decisions. "Culture power" is increasingly a real factor that drives urban politics. We illustrate this power at work with a compressed summary of our studies of local political controversies over cultural policy in Toronto.

\section{The Articulation of Culture and Creativity into City Politics: GLOBAL FaCtors}

Cultural and creative activity is growing more important in city politics worldwide. Particular cases must be situated in the context of these broader developments. We see three major trends driving this global process. Each heightens the others.

1. The rise of arts and culture among citizens. Though Putnam's Bowling Alone (2000) sparked discussion and controversy with the finding that American participation in civic associations has declined since the 1950s, he failed to detail changes in specific types of activities. There may be fewer bowling and Kiwanis Clubs, but other types of belonging are gaining salience. Indeed, as shown in Table 1, there is overall growth between 1981-2000 in cultural organization membership (like museums) by citizens in 27 out of 35 countries surveyed by the World Values Survey (only 35 include over time data by organizational type). Growth is strongest in the Netherlands, Scandinavia, the United States, and Canada, where membership in cultural organizations rose over $10 \%$ and was much higher among younger persons. Figure 1 illustrates the dramatic scale of this process in the particular case of Canada. Between 1999-2008 the number of bowling alleys, amusement and theme parks, and drinking establishments declined, while musical groups, dance companies, independent artists, and performing arts establishments increased, outpacing a total average growth rate of $14 \%$ for all businesses. 
Sports facilities and clubs also rose steeply. Many of these changes are even more dramatic in specific cities and regions, not only in Toronto and Vancouver which enjoyed large gains in many arts establishments, but in smaller places like Peterborough, ON and Penticton, BC, which saw significant increases, for example, in the number of interior design firms. This sort of transformation, far beyond what population change or income growth alone could explain, suggests a potentially major breakthrough of expressive culture and personal creativity into the populace at large.

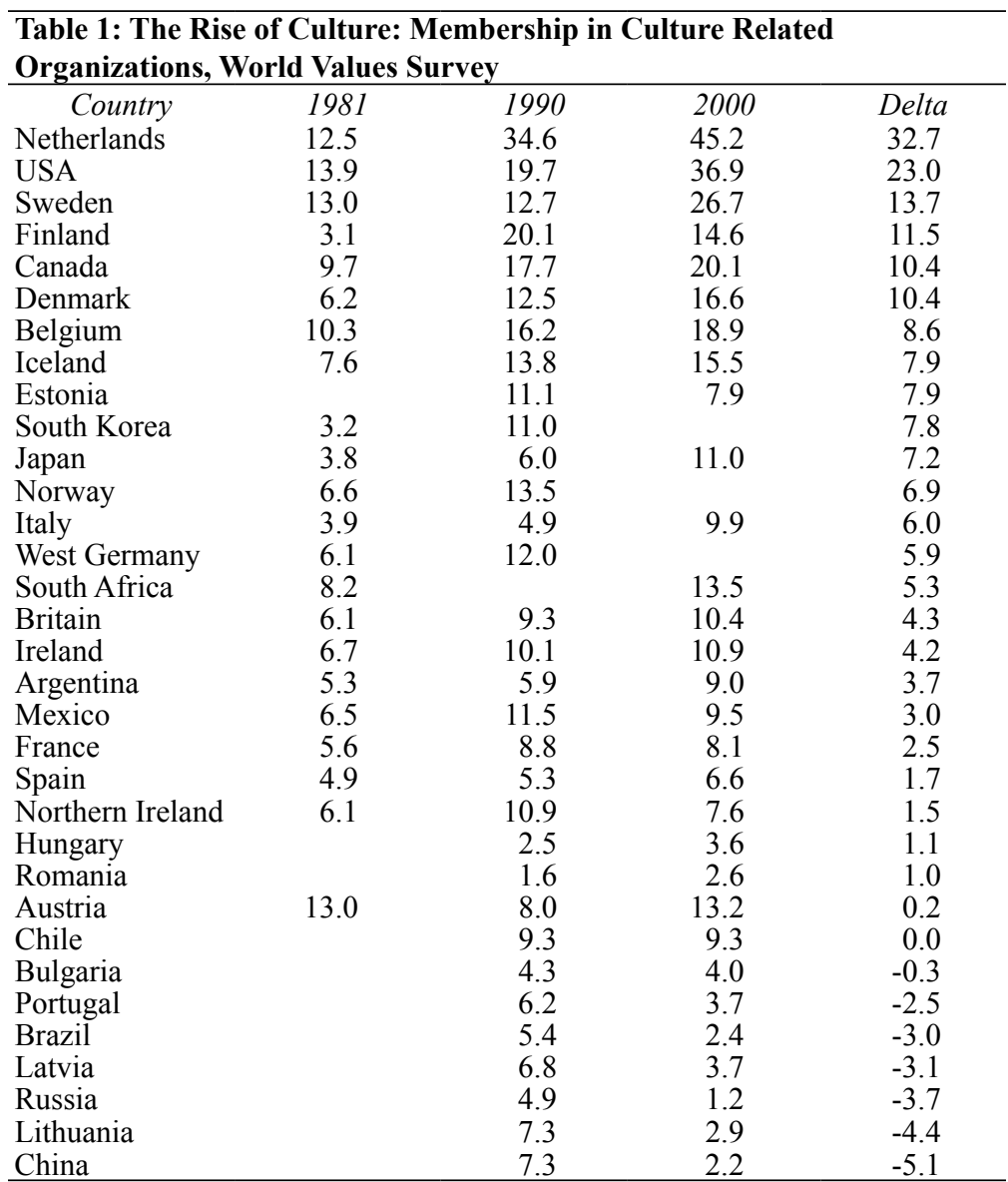

Data are from World Values Surveys of national samples of citizens in each country, about 1500/country, 3525 in the US. The three columns for each year show the percent of citizens who replied that they participated in cultural and related activities. "Delta" is the percent change from the first to last year. Question: A066. "Please look carefully at the following list of voluntary organizations and activities and say ... which if any do you belong to? Education, Arts, Music or Cultural Activities." To assess measurement error due to including education, we recomputed the results for parents and nonparents of school age children. There were minimal differences. 


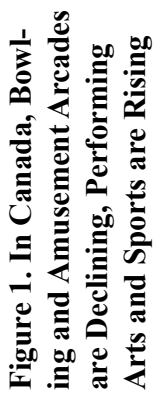

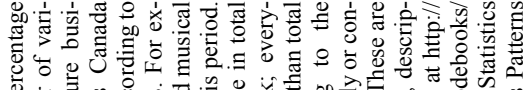

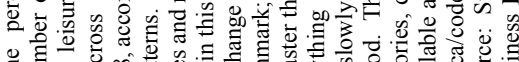

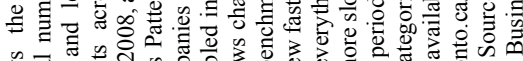

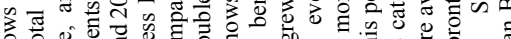

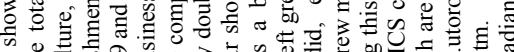
等

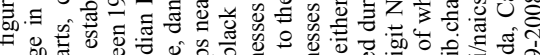

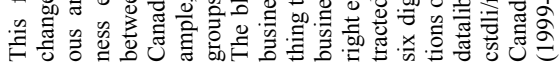

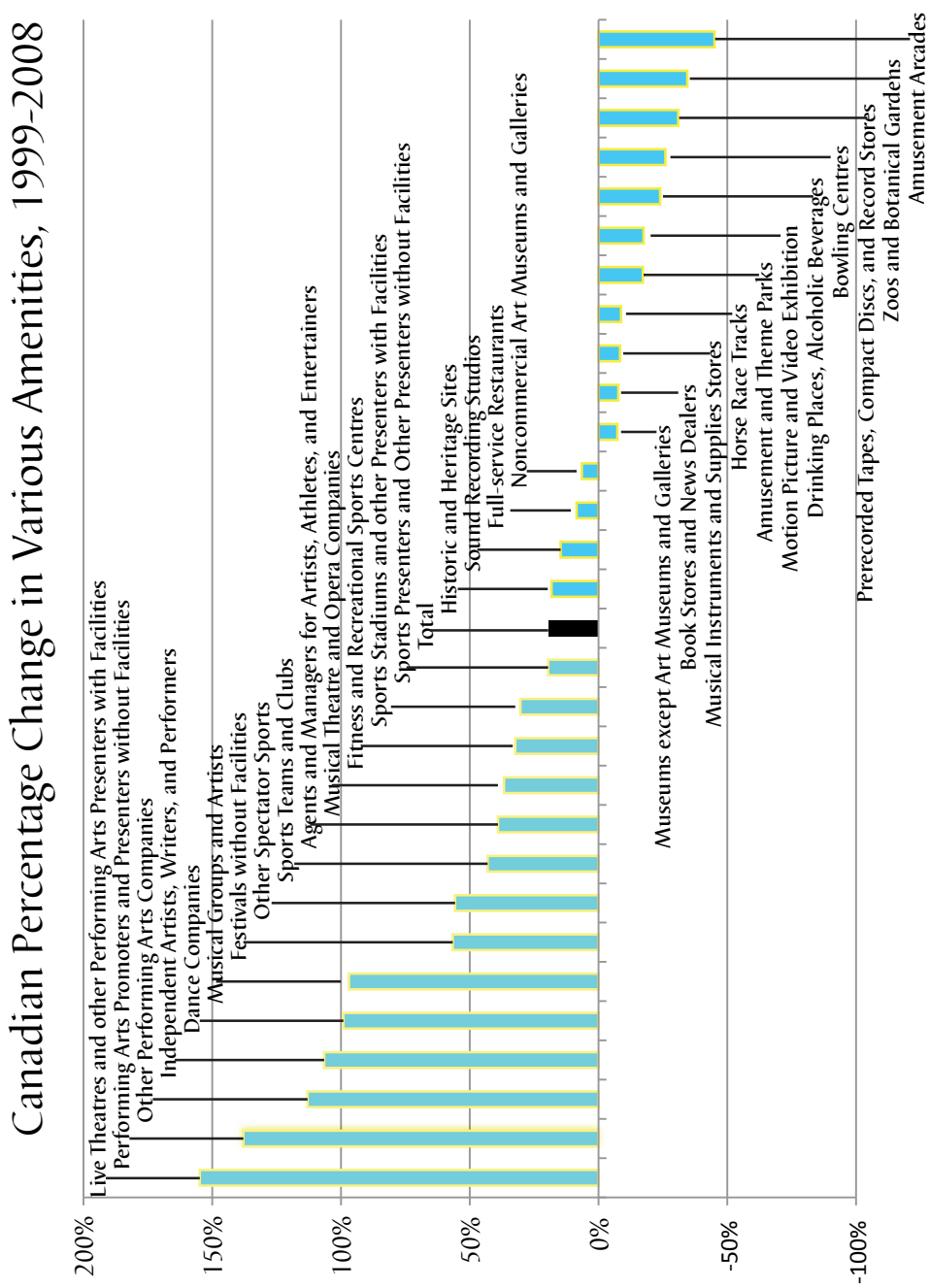


This rise is also evident in other arenas: household spending on culture, the size of cultural industries, the growth of cultural employment, and government spending. The movement is uneven across localities and not always linear within them, yet still large and crossnational. See Clark and Silva (2009) for these cross-national trends, as well as more specifics on key countries like France and Korea.

2. Rediscovery of the urbane. If the mid to late 20th century was an era of suburbanization, the early 21 st century is rediscovering and reclaiming the urbanity of central cities. Internationally there is a general rise since the 1980s in young, affluent college graduates and retirees moving into cities and especially their downtown cores, raising urban cultural tourism and stressing day-to-day urban issues such as walking, street life, adaptive reuse, and gardening (from the Paris Plage to the Times Square pedestrian zone to Toronto's Evergreen Brickworks). These movements are supported by globally oriented city governments vying for creative people, tourists, and financial capital (e.g., CEOs for Cities) and seeking to cultivate urbanist sensibilities among local citizens. ${ }^{2}$ Why? Urban analysts have mapped components of the change, yet not formulated a clear interpretation. Gyourko et al. (2006) show that the rise of downtown real estate values and rent in the largest US cities is much faster than the national average. Analogously, Cortwright (2005) presents data for all US metro areas on the dramatic increase of young persons. But these authors do not explain why; they stay close to standard census data. Richard Florida's interpretation stresses preferences of a creative class for tolerant cities. Edward Glaeser highlights increases in idea generation that arise from dense concentrations and thick networks of skilled persons. On his account, the rediscovery of the urbane is occurring because idea production has become more economically significant with the decline of manufacturing and the rise of knowledge work. Saskia Sassen suggests the importance of personal relations among global actors who prefer downtowns, and that producer services and globalization of capital are drivers. David Harvey stresses a shift from managerialism to entrepreneurialism in local governance caused by heightened interurban competition, leading cities to pursue intensive development strategies often oriented less toward local service provision and more toward cultural image and place making on the global stage (Harvey 1989, see also Brenner and Theodore 2005).

2. Florida (2010) summarizes and popularizes much of the research confirming this trend; the popularity of his Rise of the Creative Class, as well as of the work of authors like Saskia Sassen and Sharon Zukin, is in part evidence for it. 
3. Rise of a new political culture, documented in Clark and HoffmannMartinot (1998), Clark (2003), and elsewhere. Forms of political activism and legitimation are changing. Lifestyle and social issues have been rising in salience relative to party loyalty, class, and material concerns. Fiscal conservatism is increasingly joined with social liberalism; new forms of participation and legitimacy have emerged, driven less by traditional class and primordial group characteristics and more by consumption and quality of life issues, like Starbucks, NASCAR, Walmart, hunting, art galleries, and famers' markets. Ramirez et al. (2008) provide a detailed review of the literature and data for business and political salience in hundreds of North American and European local governments, documenting a striking increase in the weight given by citizens to social and lifestyle issues as well as new forms of political activism outside of traditional parties.

This process has been driven by a number of factors across multiple domains. Figure 2 summarizes these, adding a specifically cultural pathway to the model initially presented in Clark and HoffmannMartinot (1998). Economic factors include rising general affluence and high tech/information services and declines in agriculture and manufacturing employments. Social factors include the slimming family, increasing individualism, and gains in general levels of education and media access. Cultural factors include the decline of absolutist and mechanistic styles of thought and the rise of relativism,

Figure 2. Factors Driving toward a New Political Culture

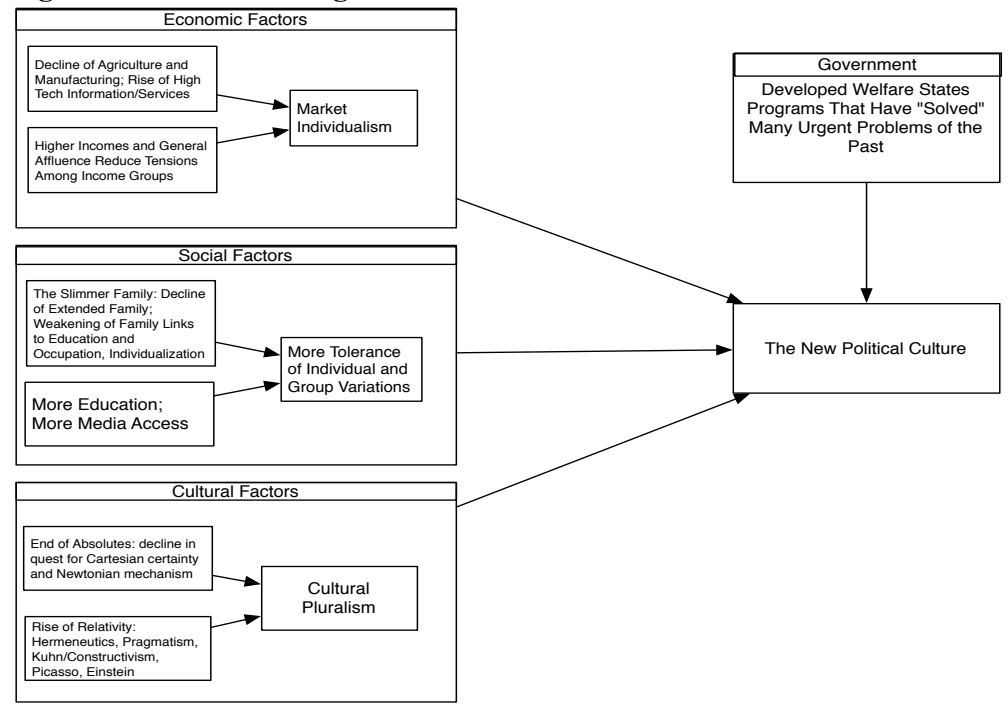


from Einstein to Picasso. Governmental factors include the welfare state and other social programs.

Our present concern is not to detail and assess the causes or nature of these processes but rather to highlight their collective impacts on city politics. Typically, these dynamics are treated in isolation, or only two out of three analyzed. ${ }^{3}$ However, all three processes generate increasing salience for arts and cultural matters as key drivers of local politics, that is, neighbourhood and city decisions, coalitions, and controversies. Figure 3 illustrates their joint operation.

\section{Figure 3. Global Factors Driving the Articulation of Culture into City Politics}

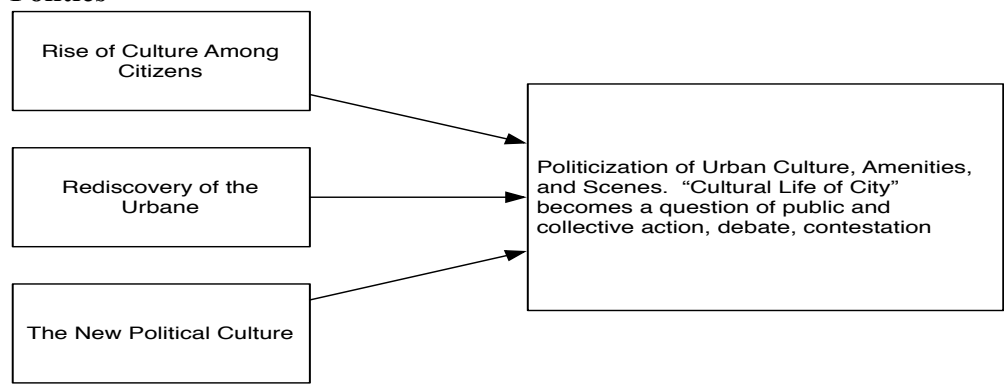

These three factors join to link culture to local politics through a number of mechanisms:

1. The rise of culture gives new importance to expressive concerns what kind of a person am I? How is this expressed in film, music, clothes, and comportment? What sorts of social audiences are in a position to appreciate and share such expressive performances of self? The goals or functional purposes of products are complemented by their design, their appeal to the personality, and meanings valued by consumers - the iPod is a prototypical case. Talcott Parsons (1971) traced the emergence of this attitude in the 1960s counterculture to a reaction against utilitarian rationalism and bureaucracy. This, he argued, recombined and heightened, in a new context, the early Christian notion of Love, 19th century Romanticism, and Eastern practices of meditation and body work. He called it the "expressive revolution" and considered it to be as world historically

3. Richard Florida and Alan Scott, for example, though writing from very different perspectives, both link regional and city growth to the rise in culture production, but leave politics out. Similarly, Edward Glaeser and Richard Lloyd — again, very different sorts of writers - link the rise in urbanism to the growth in culture industries, consumer cities, and postindustrial labour conditions, but largely omit political impacts and leaders. Clark (2003) ties variations in urban amenities to different political cultures, but pays little attention to the politics and policies of building amenities. 
important as the industrial, democratic, and educational revolutions. Noting a diffusion of what Harold Rosenberg called "the tradition of the new," where culture becomes more closely identified with modernist creativity and innovation, Daniel Bell (1973) and Charles Taylor (2007) have made similar statements, as have European authors such as Boltanski and Chiapello (2005). Dozens of case studies explore recent aspects of these trends, like those of Elizabeth Currid-Halkett (2007) and Daniel Pink (2006), some of which have made their way into more popular literature, such as Postrel (2004).

2. The rediscovery of the urbane joins quality of life to quality of place concerns. This motivates considerations about what kind of place, neighbourhood, or city enables one to pursue a life deemed worthy, interesting, beautiful, or authentic (on authenticity, see Zukin 2010 and Grazian 2003). Cultural scenes, defined by the expressive meanings projected by cafes, restaurants, music venues, galleries, bakeries, farmers' markets, and the like, become fixtures in the urban landscape and more salient in decisions about where to live and work (Silver et al. 2010). Even Logan and Molotch in the new introduction to City Fortunes stress these concerns. These expressive dynamics are enhanced by global processes including the internet and wider competition, spurring deeper searches for meaning and identity which can be distinctly symbolic in addition to the more widely discussed economic (Sassen 1994; Harvey 1989). Thus symbolic entrepreneurs can play critical roles in developing new cultural themes and products alongside financial entrepreneurs; and sometimes the two can overlap and even be identical.

3. The new political culture redefines these issues of quality, culture, and place in political terms: by emphasizing how nascent leaders and social movements champion specific lifestyle issues and consumption concerns. New questions gain political and policy traction, such as how to create attractive and vibrant scenes that offer amenities (parks, music venues, bike paths, etc.) supportive of citizens' quality of life demands; how to use these amenities and scenes as levers for economic growth, community development, and social welfare concerns; and how, for elected officials and movement leaders, to mobilize citizens' emotional allegiance to particular types of cultural activities and scenes for electoral advantage and other policy goals.

These three factors have combined to make city political and civic leaders a new vanguard party reshaping cities in a more culturally expressive direction (cf., Pasotti 2009; Lees 2003; Smith 2002). In 1975, Saul Bel- 
low wrote, "there were beautiful and moving things in Chicago, but culture was not one of them" (Bellow 1975:69). Yet by 2009, the Director of the National Endowment of the Arts could say: "Mayor Daley should be the No. 1 hero to everyone in this country who cares about art" (in The Theater Loop 2009).

\section{The Articulation of Culture into City Politics: Local Logics}

The bearers or agents of these new processes grew more active after the 1970s via "New Social Movements" (NSMs). They drove many cutting edge issues emerging in the closing decades of the 20th century. They extended both individualism and egalitarianism. They also joined consumption and lifestyle issues with the classic production and workplace concerns championed by unions and parties. These new civic groups pressed new agendas - ecology, feminism, peace, gay rights, etc. - that the older political parties ignored. Over time other aesthetic and amenity concerns also arose, such as suburban sprawl, sports stadiums, flowers, museums, and walkability. In Europe, the national state and parties were the hierarchical "Establishment" opposed by the NSMs. In the United States, local business and political elites were more often the target. Many governments were often seen as closed to these citizen activists. For instance, in the 1970s in Italy, even communists and socialist parties rejected the new issues.

Opposition of this sort encouraged the more informal organization of the NSMs and their often confrontational tactics. But as some political parties and governments embraced the new social issues, the opportunity structure (Della Porta et al. 1999; McAdam et al. 1996) drastically shifted. Movement leaders then broke from "urban guerilla warfare" and began participating in elections, lobbying, and advising governments. As their issues were incorporated into the political system, their demands moderated. Yet they added a heightened sensitivity to the emotional, musical, image-driven, and theatrical aspects of life (McDonald 2006). Correlatively, developers and politicians grow more green and artistic, as they refashion concepts like loft living or Boho into their rhetoric and policies. They add managerial know-how and political clout to the NSM concerns. "Creativity" emerges as a more general value, shared by entrepreneurs and artists.

This fairly abstract and general "moderating" process of linking 1960s countercultural social movements with official city politics has varied by local context. Arts policies have often risen out of new social movements, with a marked bohemian past. Some arts groups oppose the 
transition into more established leadership roles; others support it. Yet once this "categorical" leap into a city politics with cultural concerns at its core has been made, conflict does not disappear. It is reframed over access to, control over, and utilization of the city's cultural and expressive spaces and resources. New issues become hotly contested: attracting tourists or new globetrotting "creative class" residents vs. cultivating local artists and distinctive scenes; building downtown condominium developments for yuppies and "ruppies" (retired urban professionals) vs. promoting creative industries and organic, more countercultural scenes; treating art and artists as public goods vs. devoting municipal funds to public housing, welfare, or growth; stressing grants to individual artists or focusing on place-building initiatives; subsidizing major cultural institutions like the museum or opera to attract corporate investment or incubating grass-roots and independent scenes for the purpose of community development in residential areas outside of downtown glamour districts; joining artistic and economic interests in a growing cultural economy vs. sustaining solidarity between marginal artists, service workers, and the poor; defining "authenticity" as innovative independent activities vs. long-term residence. In different settings even within the same city these sorts of issues are framed and interpreted differently, sometimes as dichotomous oppositions, other times as mutually supporting. But they all show a concern for arts, culture, and creativity as a part of a new urban agenda.

\section{Culture and Politics in Cities: Reframing a Research Agenda}

Artists, cultural industry representatives, and other cultural groups have in many places achieved an unprecedented centrality in policy discussions. However, translating that centrality into a seat at the table with real capacity to influence events raises a new question. What resources have been rendered newly potent and valuable by the altered opportunity structure? How have various groups been able to wield these resources within urban political contestations and specific issue areas? Exerting influence requires controlling institutionally recognized but scarce resources that others wish to have.

The answer we elaborate here is: buzz. "Buzz," we suggest, has become a valuable urban resource, one generated by vibrant urban cultural scenes and sought after by residents, businesses, and political actors. Buzz signals that significant aesthetic experiences are available to be consumed in a given place, that "something is happening" (Currid and Williams 2009). Yet buzz is often produced and controlled by cultural 
actors such as artists and "bohemians," who are (relatively) low in other resources like money, political office, or local trust. Accordingly, as the value of buzz has generally increased, conflicts over controlling its production, distribution, and consumption are reshaping city politics, giving new groups access to power and creating potential coalitions between them and older institutional actors. How can we reformulate research agendas into the culture and politics of cities to include this political aspect of the rise of culture?

\section{A New Theoretical Framework}

Most past work on urban culture and municipal cultural policy has not linked politics, political actors, and citizen activism of the sort discussed above to "culture-led" urban development. Research instead tends to focus on the economic impacts and drivers of cultural development or on policy mechanisms divorced from political culture. Despite this neglect, there have been some efforts to link cultural policy with city politics, such as Markusen (2006), Indergaard (2009), McGovern (2009), Barber (2008), Catungal and Leslie (2009), and Grodach (2012).

We applaud these recent efforts to join culture, politics, and development, and build on some of their insights to interpret these new processes. We go further by situating cultural policy disputes within a more systematic theory that includes "cultural power" among multiple bases of influence over urban politics, stressing interchanges across and variations within subgroups, contextual shifts in how various resources are weighted, and how these transform the content of key policy issues. ${ }^{4}$ Substantively, this means that knowing a leader works in business does not explain much of her specific policy views. This is far more evident when one considers policy issues like improving public schools or building an art museum. These sorts of issues have no simple, direct relationship to any single business, in contrast, for instance, to a business that

4. For instance, much past work on community power and urban leadership has tended to classify leaders by their (generic) social backgrounds, such as business, political, Catholic, or Italian. This was the most commonly reported data in many historical studies, even Dahl's (1961) history chapters of New Haven. Similarly, Markusen treats "artists" as a relatively homogenous progressive political block against business and professional elites - even though their issue-specific concerns (aesthetic, political, residential, etc.) might be very different. Indeed, as Catungal and Leslie (2009) have shown, political differences may arise from divisions between commercial and "aesthetically pure" artists. McGovern's downtown "creative class" activists influenced city politics in Philadelphia, while the similar groups Indergaard studied in New York were less effective; political leaders in Reno were relatively unresponsive to the amenities concerns of the local population, whereas Vancouver, Toronto, and Chicago leaders have stressed these in their cultural policies. The issues may be similar, but the local contexts and coalitions clearly shifted the outcomes. The analytical question is to determine the conditions and factors that account for these shifts. 
sells rock salt to the city. Consequently, if we look at engagement of political, business, and cultural leaders in specific issues, we find some on one side, and others opposing them. How do they divide? It may be useful to classify policy issues and participants with more general norms and values such as "maintain the stable middle class neighbourhood," or "go bohemian," or "protect high art" or "grow commercial cultural industries."

These concerns are quite different from those of the regimes in most urban studies, which are more narrowly business oriented. ${ }^{5}$ We introduce them here to convey the importance of conceptualizing and investigating the whole array of resources at stake in urban politics, beyond but still including money and power. Social movements researchers have similarly stressed the importance, for instance, of identity and solidarity in addition to money and power. Observers of Chicago have highlighted the relative autonomy of politics from business, where economic growth often serves as a vehicle for holding political power rather than the other way around. Yet neither group solidarity, nor money, nor political power seem sufficient to capture the distinctive resources through which arts and cultural movements and industries are at least sometimes able to exert influence over city policy and exploit the political opportunities opened up by the large-scale transformations discussed above. What the arts have, we suggest, is "buzz." And buzz is based not in a city's economic and business infrastructure, not in its residential communities, not in its political apparatus. It lies in its cultural scenes.

Industrial Clusters, Residential Neighbourhoods, Political Arenas, and Cultural Scenes

By "scene" we refer to the aesthetic or ambient character of a place, the way a place offers experiences, dramas, and meanings to be enjoyed or rejected by potential consumers. A city's scenes are thus more than its physical spaces, occupational bases, political parties, and groups of persons labeled by demographic characteristics, although these all contribute to its scenes. Scenes also express the distinct aesthetic energy generated by numerous activities like dancing, sharing meals, listening to music, visiting galleries, sipping coffee, strolling plazas, attending street festivals, film openings, and the like. These join to paint an attractive and compelling urban scene: here is a place for glamour, there for transgression; here for tradition, there for self-expression (Silver et al. 2010).

5. Still the regime label is sufficiently open that it could be broadened to include cultural concerns as we suggest here, just as Ferman (1996) suggested added framing and political culture to regime analysis. 
Table 2 contrasts scenes with other ways of treating places, as industrial districts, residential neighbourhoods, and political arenas. Each defines a specific issue area and resources for influencing urban affairs: for residents of neighbourhoods, citizens of governments, producers of goods and services, and consumers of experiences and amenities. From the producer's standpoint, places are composed of workplaces and organized to facilitate the production, distribution, and exchange of goods and services. They are industrial clusters that, when successful, generate money for firms and workers. From the resident's standpoint, places are composed of residences - houses, apartments, condominiums, etc. - and organized to facilitate life's basic needs and services such as housing, safety, sustenance, childrearing, and sleep. They are residential neighbourhoods that, when successful, generate trust among community members that communicates their solidarity. For politicians, parties, and citizen activists, places are typically power centres — party offices, polling places, organizational headquarters, city government offices, etc. - and organized to support collective goal attainment, coalition formation, conflict resolution, and the exercise of authority. They are political arenas that, when successful, generate power communicating the capacity of actors to achieve and implement collective goals (e.g., through votes or leadership positions). From the cultural consumer's standpoint, places are collections of amenities to be aesthetically appreciated or rejected. They are cultural scenes that, when successful, generate buzz communicating the types of meaningful experience one might find there: self-expression, transgression, and glamour; local authenticity, neighbourliness, tradition, and more.

Table 2: Contrasting Cultural Scenes, Residential Neighbourhoods, Political Arenas, and Industrial Clusters

\begin{tabular}{|c|c|c|c|c|}
\hline Organization & Cultural Scene & $\begin{array}{c}\text { Residential } \\
\text { Neighbourhood }\end{array}$ & $\begin{array}{c}\text { Industrial } \\
\text { Cluster }\end{array}$ & $\begin{array}{c}\text { Political } \\
\text { Arena }\end{array}$ \\
\hline Goal & $\begin{array}{l}\text { Expressing and } \\
\text { communicating } \\
\text { feelings, experi- } \\
\text { ences, moods }\end{array}$ & $\begin{array}{l}\text { Necessities, basic } \\
\text { services, housing, } \\
\text { schools, safety, } \\
\text { sanitation, community } \\
\text { development }\end{array}$ & $\begin{array}{l}\text { Works, } \\
\text { products }\end{array}$ & $\begin{array}{l}\text { Collective } \\
\text { action }\end{array}$ \\
\hline Agent & Consumers & Residents & Producer & $\begin{array}{l}\text { Citizen/lead- } \\
\text { er/officials/ } \\
\text { activist }\end{array}$ \\
\hline Physical units & Amenities & Homes/apartments & Firms & Power centres \\
\hline $\begin{array}{l}\text { Basis of } \\
\text { social bond }\end{array}$ & $\begin{array}{l}\text { Lifestyles/ } \\
\text { sensibilities }\end{array}$ & $\begin{array}{l}\text { Being born and raised } \\
\text { nearby, long local } \\
\text { residence, heritage }\end{array}$ & $\begin{array}{l}\text { Work/ } \\
\text { production } \\
\text { relations }\end{array}$ & $\begin{array}{l}\text { Ideology, } \\
\text { party, issues, } \\
\text { citizenship }\end{array}$ \\
\hline $\begin{array}{l}\text { Symbolic re- } \\
\text { source }\end{array}$ & Buzz & Trust & Money & Power \\
\hline
\end{tabular}


This multidimensional approach to urban places makes four new theoretical contributions to urban politics and policy studies. First, it identifies key dimensions for coding empirical variations across cities and neighbourhoods. Some do all four of these; others just one or none. Second, it stresses that no one of these domains provides an adequate conceptualization of current urban policy, politics, culture, and economic development. Analysts need to pay more heed to all four components to avoid omitting critical processes. It thus extends the issue specificity of Dahl (1961) and arenas focus of Lowi (1964) and Peterson by adding cultural content via scenes. Third, it encourages new forms of research questions about the interchanges across the four domains: What sorts of productive activities support what type of scene, and vice versa? What sorts of residential communities support what types of scene, and vice versa? What types of scenes empower what sorts of governments and political movements, and vice versa? Fourth, it lists specific new types of symbolic resources - buzz - that play more central roles than identified in most past research on urban politics.

\section{Buzz as a Symbolic Resource}

The idea of symbolic resources in general and the notion of buzz as such a resource deserve elaboration. The central notion is that different forms of social activity are communicated through different symbols. For instance, money facilitates economic activity by providing producers and consumers with symbolic representations of valuable goods and services. Power facilitates collective action through communicating shared symbols of authority and efficacy, such as political office, elections, and official policy documents. Trust facilitates residential community through communicating shared symbols of mutual support and good faith, as in parent-teacher association membership stickers, neighbourhood watch signs, well-groomed lawns, and the like. Parsons (1971), Alexander (1987), and Lidz (2001) provide useful accounts of this general approach to symbolic media as well as studies of particular media.

We suggest that participants in cultural scenes communicate the available experiences of scenes to one another through a symbolic resource we designate "buzz." The buzz around a scene signals the distinctive types of experiences participants can expect to enjoy in a scene. For instance, film festivals, high fashion, and movie stars might generate buzz that communicates the presence of a glamorous scene; tattoo parlors, punk music, body art, and piercing studios generate the buzz of a more transgressive scene; antique stores, farmers markets, and local 
arts festivals generate buzz communicating a local scene. ${ }^{6}$ Such symbols signal the presence of the scene to a wider audience, potentially drawing in new participants and enabling persons from multiple backgrounds to share similar experiences.

\section{The Two Faces of Buzz}

Buzz, like all symbolic media, leads a kind of double existence (Alexander 1987). It faces in two directions. On the one side, buzz enables participants in scenes to communicate and circulate the experiences of the scene for their own sake. This is the autonomous face of buzz. It indicates for participants the chance to, for instance, express original feelings rather than conform to pale imitations, stay true to rather than do violence to a tradition, shine glamorously rather than fade into anonymity, project warmth and intimacy rather than distance and aloofness, maintain an authentically real life rather than a phony existence. The autonomous face of the buzz around a scene communicates the "internal life in scenes" (Hitzler et al. 2005), where success in the scene - being glamorous, self-expressive, transgressive, traditional, locally authentic, ethnically authentic, etc. - is its own reward.

In its other aspect, a scene's buzz faces outward, towards the economic, political, and residential environments with which scenes interact. This is the heteronomous face of buzz. On this level, the buzz of the scene makes functional contributions to the internal needs of these other domains. It creates the wealth, power, and trust through which the scene can potentially earn its keep in the broader system of which it is a part. Conversely, scenes can receive external support from business groups, political actors, and residential groups in the form of money, political assistance, and community trust. Where, for instance, the strong buzz around a more independent and self-expressive scene has drawn significant attention, investment, and personal emotion from the wider city, scene representatives are likely to be able to act more effectively to preserve and grow their scene relative to representatives of less buzzing scenes with similar sensibilities, elite support, and financing. The greater

6. In the formal language of our theory, we refer to the specific buzz of a scene by appending "ies" to the experiential dimensions of scenes. That is, a scene that signals high levels of transgressive experience does so by projecting large volumes of "transgressies," glamorous experiences are signaled by "glammies," and neighbourly experiences are signaled by "neighbies." This means that some places can be, so to speak, all sizzle and no steak (high buzz but low experience) or vice versa (powerful experiences with little buzz signaling them). Our analyses of such buzz, for all 42,000 US zipcodes, are detailed at http://scenes.uchicago.edu. One finding is that glammies are stronger in explaining economic growth than cost of living, crime, and population size. Buzz is not just fluff. Currid-Halkett and Williams (2009) provides a potentially valuable way to develop empirical measures of buzz. 
these interchanges, the more deeply these particular scenes are likely to become enmeshed into the social fabric of a city. The opportunity to connect with scenes would become a part of the day-to-day cultural needs of residents, businesses, and political officials just as scenes and scene supporters become more deeply concerned with their own contributions to neighbourhood issues, economic development, and local governance. How can we describe in more detail these hypotheses about the dynamic interchanges between scenes and the other aspects of urban life?

\section{Urban Politics as Resource Interchange, Boundary Work, and Symbolic Inflation Management}

The points of contact among the domains highlighted in Table 2 are where much of the conflict and creativity in a city occurs, where habits and sensibilities from one arena enter into the other and are redefined, rejected, or assimilated. Consider: A developer is in the business of extracting economic value from new buildings. This endeavour is not intrinsically aesthetic, but it can be 1) enhanced if the buzz of the surrounding scene attracts attention and investment, 2) authorized or stymied by the power of political regulations, and 3) legitimated or delegitimated by the influence of local residents. Buzz, political power, and community influence are inputs into the economic process. At the same time, from the perspective of scene enthusiasts, the developer's cash and the politician's authority might in some circumstances enable the scene to continue to express and share the experiences that it cultivates. Similarly, to the extent that political support for city politicians depends on meeting citizens' quality of life demands and lively scenes are key providers of what makes for quality urban living, then buzzing scenes will provide key inputs useful for the exercise and maintenance of political power; politicians would be more likely to express solidarity with local scenes and scene-makers. If active scenes enhance community and neighbourhood trust, then local neighbourhood leaders, who depend on that trust to wield their influence, will be increasingly dependent on cultivating the artists, cultural groups, and amenities that generate vibrant local scenes. At the same time, support from influential neighbourhood leaders can earn scenes solidarity with residents who are in turn more likely to treat the scene as a neighbourhood asset rather than a source of deviance and instability.

Interchange does not mean agreement. At every point, there is opportunity for political struggle, coalition, and for creative reinterpretation of business, aesthetic, neighbourhood, and political practice. For instance, a community leader who seeks to build trust among neighbours through 
growing a local cultural scene stakes her influence on the scene engaging rather than enraging local residents' sensibilities. Aesthetic disagreements about art and artists become intertwined with disagreements about the nature of the community. Political leaders who seek to win elections and mobilize citizen action through cultural policies stake their political power on the scene enriching citizens' lives. They would have to deliver the cultural goods, and failure to do so could be politically damaging. Scene enthusiasts who grow their scenes by using its buzz to attract money, political clout, and residential community support may make the ongoing vitality of the scene more dependent on generating wealth, power, and local trust. They may face charges of co-optation, selling out, and domestication. And conversely, often amidst rising rents, increasing property values, and new condominium developments, scenes may need to deliver some return on their buzz in the form of financial subsidies, political backing, and residential solidarity that keeps the scene solvent and anchored in terms of its characteristic experiences and practices.

Cultural scenes may create other forms of policy debates. Their buzz may become "inflated," decreasing its power to provide reliable signals about what experiences a scene offers. That is, as buzz expands, more people may come to possess the external symbols of the scene. This can reach a point that possessing such symbols (wearing T-shirts, owning music tracks, reading certain magazines, preferring certain interior décor) is not a clear indication of a person's readiness to engage fully in the emotions and practices that "back" the scene's buzz, diluting its symbolic potency and expressive energy. Similarly, buzz "interest rates" may vary, with some pursuing expansionary policies to lend buzz with few strings attached (as in pop music or a club district) and with others placing high costs on borrowing their buzz (as in Goth music or perhaps the classic local Chicago pub). Low interest rates in buzz may attract considerable investment in a scene (in monetary and other forms), if many people decide to give it a try. This can lead to rapid growth but also to unsustainable inflation. High interest rates in buzz may drive up the price of participation, making the scene more exclusive (and the rent higher), as in scenes that place limits on expansion to preserve their authenticity. Zukin's (2009) discussion about political-economic dilemmas around the desire to preserve authenticity of places like New York City's lower east side is one recent case in point.

More generally, many city officials have responded by crafting policies designed to build up their cultural assets and scenes to bring tourists, new businesses, and residents; retain and energize those they have; and channel the often abrupt transitions from neighbourhood and industrial district to new buzzing scenes filled with amenities and consumption 
spaces. Archetypical examples are the renovated railroad station with "authentic" stone and steel framing a chic restaurant/bar (cf. Zukin 1982) or housing community arts groups and farmers' markets. At the same time, groups who provide key inputs into the production of buzz may threaten to withhold their services and cut the supply and quality of buzz attached to a given place. These groups could include artists, photographers, writers, promoters, and performers, among others. Insofar as the profitability of that place's businesses, the social cohesion among its residents, and the election results of its politicians depend on that buzz continuing, this withdrawal could conceivably constitute a major threat. It would be a buzz strike. ${ }^{7}$ Moreover, some places have encouraged buzz inflation, encouraging rapidly growing tourist and club districts; others have pursued "sustainable" growth in buzz, restricting restaurant and liquor licenses in order to more slowly integrate an emerging scene into existing residential neighbourhoods and industrial areas. These sorts of policy decisions we suggest offer a critical piece of the interpretation omitted by the more descriptive studies of rent or migration like Gyourko et al. and Cortwright cited above.

Such interchanges, boundary work, inflationary cycles, and policy decisions create new ways to influence urban affairs and new problems for policy makers to address. Empirically, these processes likely vary considerably, and investigation into these variations need to be guided by clear propositions about where and why they might differ. Such as:

- Where local politics are more tightly coupled with national politics, governments may be more likely to support cultural organizations whose buzz extends nationally or internationally.

- In conflicts among residents about integrating a scene into their neighbourhood, the moral contribution of local artists' buzz to the local community (i.e., building vs. undermining trust) may become an important political controversy. It should vary with the cultural/ scene distance of the arts groups from residents.

- In conflicts between residents and arts professionals over cultural developments (e.g., building a new museum), residents may be concerned about impacts of heightened buzz on neighbourhood issues (e.g., traffic and home prices) while artists and arts management professionals (curators, museum directors, etc.) may operate from a more cosmopolitan perspective (e.g., judge local projects in reference to global icons).

7. Stinchcombe (1968:119) observes that labour strikes were not a usurpation of an existing form of power by a new group but rather were a new way of exercising power, linked with the rise of labour markets and formally free employment. Buzz strikes are a similarly new form of power, linked with the rise of culture. 
- Where conflict revolves around industrial policy to subsidize local scenes, the productivity and wealth-generating consequences of area artists' buzz may become central political issues.

- In a patron-client political culture, political leaders will tend to resist generic cultural planning frameworks and instead support specific participants separately to build particular and personal buzz dependencies and loyalties rather than generalized policy resources equally accessible to all. Conflict will revolve around movements pushing for "reform" and seeking to develop an "artist class consciousness."

- When historically countercultural scenes begin to cooperate with established business interests, political organizations, and residential groups, internal critiques may arise from within the scene asserting that their buzz is being, respectively, sold out, co-opted, or domesticated. Internal controversy will revolve around the scene's capacity to deliver its core cultural experiences and integrate new participants as it grows and becomes more interdependent with other domains.

In sum, as the rules of the game shift across political systems, so do the impacts of resources: money talks in a business dominant power structure, but votes count more in an egalitarian system. Hypothetical examples of shifts in resource impact are listed in Table $3 .^{8}$

We offer (without demonstrating) these propositions to illustrate the sort of analysis encouraged by pursuing the links between cultural pol-

Table 3: Political Contexts Shift the Value of Resources

Ideal Types of Political Systems

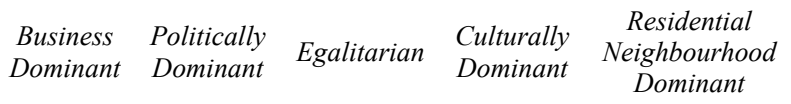

Resource types

\begin{tabular}{lccccc} 
Money & H & M & L & L & L \\
$\begin{array}{l}\text { Votes } \\
\begin{array}{l}\text { Community } \\
\text { influence }\end{array}\end{array}$ & L & M & H & M & M \\
$\begin{array}{l}\text { Political leader } \\
\text { access }\end{array}$ & L & H & M & M & H \\
Aesthetic buzz & L & L & M & H & M \\
\hline
\end{tabular}

$\mathrm{H}=$ High; $\mathrm{M}=$ Medium; L=Low.

This matrix illustrates how resources shift in their impact in different political contexts. It highlights resources and contexts of the sort we stress in this paper, separating two types of power, votes and political leader access. Other resources may be more salient in different settings. The differences in impact are due to shifting rules of the game across different contexts. Example: as Chicago's traditional political dominance has declined, so do the impacts of those resources most important for a politically dominant power structure.

8. Parsons and Dahl discussed resources which Clark, J.S. Coleman, and A.L. Stinchcombe codified in exchange matrices showing how resources could shift in prices. This paper extends the logic one step further by codifying how cultural and aesthetic criteria can shift the value/prices of other distinct resources. See Clark (1973:ch. 4). 
itics and the many concepts from the overlapping literatures we have invoked: resources, exchange, issue areas, inflation, buzz strikes, etc. Many more could be pursued and these could be empirically tested. Our main theoretical concern however is to suggest that cultural practice can be analyzed using such concepts, and that they are no more evanescent or intractable than a taste for a new beer or style of lawn or more standard local politics issues such as zoning and sanitation. Simultaneously, we point cultural political analysts to these overlapping theories since they suggest ways to interpret culture more powerfully and precisely.

\section{Buzz in Toronto Local Politics}

We conclude by briefly illustrating some of these processes in the case of Toronto, which in the past decades has seen dramatic increases in the centrality and salience of cultural policy in its municipal politics. This account is based on interviews with culture department officials, arts activist organization leaders, Toronto Artscape officials, Toronto Arts Council officials; city staff reports, Ontario Municipal Board documents; and media coverage. A more detailed study of the politics of cultural policy in Toronto is available in Silver (2012).

Against the backdrop of a strong Victorian heritage suspicious of public amusement (Lemon 1984), large-scale cultural development began in Toronto, and Canada, around the national centennial in 1967. Artist groups, often with counterculture sensibilities, won grants for homegrown Canadian culture. These supported Toronto's first Marxist theatres, independent art galleries, and new music venues (McKinnie 2007; Churchill 2010). Over the next 40 years, many arts advocates found their way into the city's culture department, bringing with them a strong personal commitment to their work. Cultural activists, in other words, with initial and enduring commitments to vital scenes as public goods, brought concerns about buzz creation into City Hall.

Arts and cultural concerns were steadily integrated more deeply into many key civic, economic, political, and community organizations. Proclaiming "I am an artist and I vote," civil society groups like Artsvote began to exert influence on local elections by holding (highly publicized) mayoral debates and issuing report cards about how arts-friendly candidates for city council are. Toronto Artscape became a major force in developing artist-friendly housing and community development, often extracting significant government subsidies for below-market artist residences. The culture department officially merged with economic development, resulting in a full-time staff member within the latter as an 
official liaison between the two; it also built informal bridges with the planning department and hired a planner onto its own staff. Buzz was slowly and steadily being officially recognized as a vital urban resource across numerous organizations and actors.

A much publicized controversy in the neighbourhood of West Queen West between 2005-2008 illustrates how these buzz-infused organizations provide resources for activists to intervene in city politics, as well as how local cultural political controversies and creativity often occur in the interplay of buzz with other resources. Starting in the mid to late 1990s, large numbers of mostly young, single artists and cultural workers moved into the former industrial area. Rents were relatively cheap, and, as manufacturing left, the old warehouses provided attractive artist live-work spaces, many of which were semi-legally appropriated for that purpose. Moreover, the area was ripe with the "grit as glamour" that Richard Lloyd (2006) suggests is often attractive to "neobohemians" looking for life on the edge. Easy access to the iconic Queen Street scene - a historical centre of independent and alternative art worlds - was important as well, for galleries, shows, professional contacts, and identity.

By 2001 the area had the fifth most artists as a share of the local population in Canada and was in the midst of nearly a five percentage point increase in the share of the population working in arts, culture, and recreation between 1996-2006 (Statistics Canada data, compiled by authors). The neighbourhood has about 9 times as many art galleries as the average Toronto postal code, is a centre of Toronto's design industry (graphic, interior, software, and more), and has large numbers of tattoo parlors. ${ }^{9}$ Concurrently, the share of the population that was married with children dropped, down 8 points between 2001-2006 alone (Statistics Canada data, compiled by authors). In short, the area became a focal point of artistic and creative work, with a strong orientation toward personal experimentation, youthful self-expression and discovery, and spontaneity.

The buzz of the scene was also attracting new participants and new investment. More new private dwellings were built in the surrounding political ward between 2001-2006 than in the previous 10 years. Thousands of new units were under construction in 2012. Rents were on the rise, and core scene participants began to worry about its solvency.

Two concerns were crucial, politically. First, the rapid influx of new residents threatened "buzz inflation" as discussed above, where symbols become valued above the experiences that back them. Local media re-

9. These figures are based on yellow pages data compiled by the authors. M6J, the postal code in which West Queen West is located, has 27 art galleries, compared to 2.5 in the average Toronto postal code; 5 tattoo parlors compared to .5 in the average Toronto postal code. 
corded the concern. "Suddenly, the Queen West Triangle was the epicentre of the city's cultural buzz, and everyone wanted a piece of it" (Preville 2007). "The ratio of 'normal people' to 'artists with cool hair' will be thrown into upheaval" (Whaley 2007). And another: "Those condo owners will discover that much of the authentic local culture they bought into will have disappeared when they want to sell. It's a bad investment unless the cultural fabric of the neighbourhood can be protected and nurtured" (Kuznicki 2007). These general sorts of worries were shared by city officials as well, who were concerned about maintaining a critical mass of working artists in the area so as to sustain "the [neighbourhood's] buzz with respect to being a centre of creative expression" (City of Toronto 2006:8). Here we see strong official and public acknowledgment of buzz as a valuable resource and explicit concern with buzz inflation as an urban political problem.

One of the most potent symbols of this perceived threat of buzz inflation was in the name and advertising of one of the new condominiums: The Bohemian Embassy. Referencing a local bar central to Toronto's 1960s bohemian culture in the Yorkville neighbourhood (a hangout for Joni Mitchell and others), this name, together with glossy photos of beautiful and decidedly unbohemian people, evoked visceral disgust. A local artist turned this disgust into art, projecting onto a wall near the proposed development an image of a woman dressed like the one in the advertisements, but vomiting.

These graphic reactions detailed the threat, as scene participants saw it. The new developments would drastically reduce the availability of artist workspaces in the area, as existing spaces would be rezoned for residential uses. This would in turn shift the balance of the scene away from a healthy and relatively autonomous mix of buzz production and consumption to a seemingly empty, externally oriented, and inflated buzz consumption. The scene would exist primarily as a weekend pastime for residents whose energies and interests were oriented elsewhere, diluting its expressive and emotional energy. A dwindling core of available workspace would deplete the number of committed full-time participants, and the scene's "artistic heart" would be in danger. Indeed, many artists and core participants had already started moving further west and north before public controversy about these developments emerged in the mid2000s.

Second, increased development, in line with our propositions above, raised concerns that the very desire to integrate buzz into the fabric of the evolving community would disturb the organic spontaneity of its core identity. No one person planned the neighbourhood as an artist colony; people simply started moving into warehouse spaces and making them 
studios. Galleries burst up here and there, with no blueprint. Being a part of that flowering was part of the aesthetic allure of the scene. The proposed developments, however, to the extent that they did include artist workspaces, did so in a planned "creative mews." But this kind of planning was, for some, an affront to the scene's ethos of improvisation and spontaneity: "arts communities grow organically" (in Foad 2007).

Scene supporters, artists, local businesses, community groups, and media professionals joined in a campaign to alter the design of the proposed condominium developments. They created an organization, Active 18 , named after the area's political ward. One of their central goals was to preserve the neighbourhood's offbeat, funky, and independent scene while it grew. Movement supporters pressured city hall, activating the networks of supporters there that had been building over the years, and were able to win considerable sympathy and support, not only from the culture department but from the mayor's office as well. Using their ability to create buzz as a political weapon, they held press conferences with flashy urban design proposals to demonstrate that they could put on a show as good as the developers'. If local artists, businesses, and scene members lacked the economic resources to alter the market dynamics of local development, they could, they thought, move vigorously to mobilize resources they did command (like influence and buzz) to convince political actors to intervene via the resources they controlled - power in the form of control over zoning regulations. This in turn, they suggested, would create more economic value by preserving the core activities that had attracted investment into the area in the first place and maintaining work and not only residential uses in the downtown core of the city.

The public rhetorical case was just as crucial. Active 18 was for "good design." This message was in large measure an attempt to square the circle of spontaneity and planning, by advocating a kind of urban design that would at the same time cultivate improvisational expression. They were not simply wild bohemians looking to roam free; they were for a novel overcoming of seeming contradictions. At the same time, Active 18 portrayed themselves not as NIMBYs but called themselves YIMBYs (Yes in My Backyard). They were for development, not against it; but, so they argued, Toronto needed a kind of development that would unleash its creative potential so that its growth in cultural employment could redound to public benefit. That is, their message sought to reframe arts clusters not as the "cultural contradiction of capitalism," but as core and trustworthy pillars of the new economy, increasingly enshrined as such in official city planning documents. Unconventional artists could be useful labour, and for the success of Toronto as a whole, it would be crucial to maintain an urban design in which this kind of work could 
flourish. Buzz could complement rather than contradict the city's established resource bases.

The case went before the Ontario Municipal Board (OMB), with the city joining with Active 18 in advocating for preserving significant artist workspace in the area. Specifically, the city developed an argument to the effect that developers be required to guarantee "no net loss" of "creative" workspaces. The OMB rejected this argument, on the grounds that a policy intended to protect employment must be based on objective data and more comprehensive analysis, as well as more established planning frameworks. Before the city and Active 18 won a rare appeal (pushed for by Mayor Miller), the city had already settled with developers on two of the three specific proposed developments (to the chagrin of Active 18). With the threat of appeal, and with Toronto Artscape emerging as a powerful broker, the third was settled on terms more favourable to the local arts scene, with 56,000 square feet being sold to Toronto Artscape, who would own and manage the space in perpetuity as affordable artist live-work units. Developers would contribute to the repurposing of a nearby and historically significant library as a performing arts hub. They would also contribute additional funds for community arts infrastructure projects, and after some further negotiations, new park space. Though not everything Active 18 wanted - many competing and powerful resources and actors were in play, after all - these are fairly considerable concessions and elite support in a planning environment that was not set up to their benefit, ${ }^{10}$ and local arts leaders expressed optimism about the solvency of the scene. ${ }^{11}$ The nature of the long-term outcome, however, is still open.

Successful action is more than meeting specific goals, however; it is also creating an enriched platform for further action (Silver 2011), which in this case means integrating recognition of the significance of buzz for urban development and sustainability more deeply into the city's policy apparatus. The most significant policy impacts of this case may be at this level. Thus, Active 18 continues as a formal organization dedicated to using buzz as an urban resource. This in itself is a significant result, as they are continuing players not only in their own neighbourhood but actively training other groups city-wide looking to learn the ways of

10. Most notably, the area lacked a secondary plan, understaffing in the Planning and Legal departments made it difficult to move quickly enough to impose many controls on the development process, and the city was often trying to create policy in the course of quasi-legal process before the OMB.

11. "I'm not going anywhere, the other [arts and cultural organization] owners aren't going anywhere.... It's about making sure that the condos become more than they were intended to be. We have to make sure the people learn to care about the area. My Pollyanna dream is to make sure they do" (Christina Zeidler, in Rau 2007). 
YIMBYism. At the same time, some city officials have accepted arts activist critiques that city agencies were not properly prepared to deal with planning for place-based scene development. They have undertaken new planning initiatives in response, building closer ties between the culture department and the planning department and generating maps and inventories of cultural workers and facilities in order to potentially implement "no net loss" policies. Generating new organizational capacity and integrating cultural policy more deeply into the planning process are two crucial outcomes of political action indeed.

In sum, as the city's economic and social bases increasingly depended on arts and culture, movement activists seized the new opportunity space. The steady integration of culture into the civic, economic, and political fabric of the city provided organizational capacity for using, and official recognition of, buzz as an urban resource. The threat of buzz withdrawal became a political weapon wielded by activists to exercise at least partial influence over city planning, political leadership, and development policy to gain subsidized housing and other benefits. They slowly redefined Toronto's cultural scenes as productive and upstanding contributors to the city's welfare and stability rather than dangerous sources of social deviance. In Toronto's neoreformist political culture (Boudreau et al. 2009, Savitch and Kantor 2002), they were able to parlay the "community benefits" of buzz into power and money.

\section{Conclusion}

The case of Toronto highlights one mode of active intervention in city cultural policy, which complicates standard gentrification stories in which economics trumps politics and culture. Cities with different political culture would show different dynamics. Thus, in neoclientelist Chicago, powerful patrons - top political and civic leaders - have sought to make the city's buzz dependent on their personal grace and friendship (Clark and Silver 2012). Strong leaders and active movements, not only the unfolding of economic necessity, have put buzz onto the agenda. Their decisions take place in highly conflictual contexts, where coalition building and narrative framing are essential to what actually gets done. Understanding the resources they can bring to bear on these decisions is vital to understanding how cities are now governed.

It will take some time before academic research can confront these issues in a systematic way. If they are still new for policy makers and activists, they are even newer for urban theorists and analysts. By comparison, it took some 25 years of case studies, survey research, and in- 
tellectual debate about growth machines before Ramirez et al. (2008) could produce a systematic and empirically based morphology of mayor governing coalitions. At present, we lack survey results that explicitly probe the influence of cultural groups and initiatives across city governments and agencies. Though the international surveys of the Fiscal Austerity and Urban Innovation project have moved toward the new issues discussed here, they have only begun to add questions about culture, amenities, and scenes. Our discussion of Toronto and our similar work in Chicago (Clark and Silver 2012) move in this direction. We have encouraged others in related research in The Politics of Urban Cultural Policy: Global Perspectives (Grodach and Silver 2012), which includes some 18 case studies from around the globe, and elaboration of the Toronto case.

In such moments of intellectual and social ferment, however, theorizing of the sort undertaken here is vital to outline potential questions and connections that may not appear on the agenda of the activist or empirical researcher. This paper offers a theoretical framework for analyzing cases where politics, cultural policy, economic development, and residential neighbourhoods overlap. We build on a truly global movement of arts and culture. Yet it is not isolated from politics, despite much past rhetoric. Expressive culture is becoming deeply engaged in the social and political fabric of urban life. Our framework points at some of the local processes and actors through which the arts and culture can have impact, proposing a new concept for a newly salient resource buzz - that has in many contexts endowed new actors with a surprisingly strong influence in local politics. Toronto provides a useful site for investigating how this resource operates on the ground. But this case need to be expanded and deepened, compared to other detailed case studies, and integrated into large-scale surveys that take the politics of local cultural policy seriously.

\section{REFERENCES}

Alexander, Jeffrey C. 1987. Twenty Lectures: Sociological Theory since World War II. New York: Columbia University Press.

Barber, Alicia. 2008. Reno's Big Gamble: Image and Reputation in the Biggest Little City. Lawrence, KS: University Press of Kansas.

Bell, Daniel. 1973. The Coming of Post-Industrial Society: A Venture in Social Forecasting. New York: Basic Books.

Bellow, Saul. 1975. Humboldt's Gift. New York: Penguin.

Boltanski, Luc and Eve Chiapello. 2005. The New Spirit of Capitalism. London and New York: Verso. 
Boudreau, Julie-Anne, Roger Keil, and Douglas Young. 2009. Changing Toronto: Governing Urban Neo-liberalism. Toronto: University of Toronto Press.

Brenner, Neil and Nik Theodore. 2005. Neoliberalism and the urban condition. City 9(1):101-107.

Catungal, John Paul and Deborah Leslie. 2009. Placing power in the creative city: Governmentalities and subjectivities in Liberty Village, Toronto. Environment \& Planning A 41(11):2576-2594.

Churchill, David S. 2010. American expatriates and the building of alternative social space in Toronto, 1965-1977. Urban History Review 39(1):14-31.

City of Toronto. 2006. Request for direction report, South District Application 05199764 SPS 00 TM, Official Plan and Zoning Review in the West Queen West Triangle Area 2005199764 SPS 00 TMWard 18 - Davenport. Online. Accessed 12 February 2012 from http://www.toronto.ca/ legdocs/2006/agendas/committees/te/te060613/it005.pdf.

Clark, Terry Nichols. 2003. The breakdown of class politics. The American Sociologist 34(1):17-32.

1973. Community Power and Policy Outputs: A Review of Urban Research. Beverley Hills, CA: Sage Publications.

Clark, Terry N. and Vincent Hoffmann-Martinot, eds. 1998. The New Political Culture. Boulder, CO: Westview Press.

Clark, Terry Nichols and Filipe Carreira da Silva. 2009. Revisiting Tocqueville: Citizenship norms, political repertoires, and cultural participation. Pp. 1-32 in Mohamed Cherkaoui, Peter Hamilton, and Alexandra Frenod, eds., Raymond Boudon: A Life in Sociology. Oxford and Paris: Bardwell Press/GEMAS.

Clark, Terry Nichols and Daniel Silver. 2012. Chicago from the political machine to the entertainment machine. In Carl Grodach and Daniel Silver, eds., The Politics of Urban Cultural Policy, Global Perspectives. London: Routledge.

Cortwright, Joseph. 2005. The Young and Restless in a Knowledge Economy. Chicago: CEOs for Cities.

Currid-Halkett, Elizabeth. 2007. The Warhol Economy: How Fashion, Art, and Music Drive New York City. Princeton, NJ: Princeton University Press.

Currid-Halkett, E. and S. Williams. 2009. The geography of buzz: Art, culture and the social milieu in Los Angeles and New York. Journal of Economic Geography 10(3):423-451.

Dahl, Robert Alan. 1961. Who Governs? Democracy and Power in an American City. New Haven, CT: Yale University Press.

Della Porta, Donatella, Hanspeter Kriesi, and Dieter Rucht. 1999. Social Movements in a Globalizing World. New York: St. Martin's Press. 
Ferman, Barbara. 1996. Challenging the Growth Machine: Neighborhood Politics in Chicago and Pittsburgh. Lawrence, KS: University Press of Kansas.

Florida, Richard. 2010. The Great Reset: How New Ways of Living and Working Drive Post-Crash Prosperity. New York: Harper.

Foad, Lisa. 2007. Selling off Queen West. Now Magazine. August 23-30. 26(51).

Grazian, David. 2003. Blue Chicago: The Search for Authenticity in Urban Blues Clubs. Chicago: University of Chicago Press.

Grodach, Carl. 2012. Before and after the creative city: The politics of urban cultural policy in Austin TX. Journal of Urban Affairs 34(1):81-97.

Grodach, Carl and Daniel Silver. 2012. The Politics of Urban Cultural Policy: Global Perspective. New York: Routledge.

Gyourko, Joseph, Christopher Mayer, and Todd Sinai. 2006. Superstar cities. National Bureau of Economic Research Working Paper Series. Online. Accessed 30 March 2012 from http://www.nber.org/papers/w12355.pdf.

Harvey, David. 1989. From managerialism to entrepreneurialism: The transformation of urban governance in late capitalism. Geografiska Annaler 71B: $3-17$.

Hitzler, Ronald, Thomas Bucher, and Arne Niederbacher. 2005. Leben in Szenen: Formen Jugendlicher Vergemeinschaftung Heute. Wiesbaden: VS, Verlag für Sozialwissenschaft.

Indergaard, Michael. 2009. What to make of New York's new economy? The politics of the creative field. Urban Studies 46(5):1063-1093.

Jacobs, Jane. 1969. Economy of Cities. New York: Random House.

Kuznicki, Mark. 2007. OMB decision on Queen West: Spark a revolution. Online. Accessed 12 February 2012 from http://remarkk.com/2007/01/16/ omb-decision-on-queen-west-spark-a-revolution/.

Lees L. 2003. Super-gentrification: the case of Brooklyn Heights, New York City. Urban Studies 40:(12)2487-2509.

Lemon, J. 1984. Toronto among North American cities: A historical perspective on the present. Pp. 323-352 in Victor Russel, ed., Forging a Concensus: Historical Essays on Toronto. Toronto: University of Toronto Press.

Lidz, Victor. 2001. Language and the 'family' of generalized symbolic media. Pp. 141-176 in A. Javier Treviño, ed., Talcott Parsons Today: His Theory and Legacy in Contemporary Sociology. Lanham MD: Rowman \& Littlefield Publishers.

Lloyd, Richard. 2006. Neo-bohemia: Art and Commerce in the Postindustrial City. New York: Routledge.

Logan, John R. and Harvey Molotch. 1987. Urban Fortunes: The Political Economy of Place. Berkeley, CA: University of California Press. 
Lowi, Theodore J. 1964. American business, public policy, case-studies, and political theory. World Politics 16(4):677-715.

Markusen, Ann. 2006. Urban development and the politics of the creative class: Evidence from a study of artists. Environment \& Planning $A$ 38(10):1921-1940.

McAdam, Doug, John D. McCarthy, and Mayer N. Zald. 1996. Comparative Perspectives on Social Movements: Political Opportunities, Mobilizing Structures, and Cultural Framings. New York: Cambridge University Press.

McDonald, Kevin. 2006. Global Movements: Action and Culture. Malden, MA: Blackwell.

McGovern, Stephen J. 2009. Mobilization on the waterfront: The ideological/ cultural roots of potential regime change in Philadelphia. Urban Affairs Review 44(5):663-694.

McKinnie, Michael. 2007. City Stages: Theatre and Urban Space in a Global City. Toronto: University of Toronto Press.

Parsons, Talcott. 1971. The System of Modern Societies. Englewood Cliffs, NJ: Prentice-Hall.

Pasotti, Eleonora. 2009. Political Branding in Cities: The Decline of Machine Politics in Bogota, Naples, and Chicago. New York: Cambridge University Press.

Pink, Daniel H. 2006. A Whole New Mind: Why Right-Brainers Will Rule the Future. New York: Riverhead Trade.

Postrel, Virigina. 2004. The Substance of Style: How the Rise of Aesthetic Value is Remaking Commerce, Culture, and Consciousness. New York: Harper Collins.

Preville, Philip. 2007. Bedeviled triangle. Toronto Life June.

Putnam, Robert. 2000. Bowling Alone: The Collapse and Revival of American Community. New York : Simon \& Schuster.

Ramirez, Antonia Maria, Clemente J. Navarro, and Terry Nichols Clark. 2008. Mayors and local governing coalitions in democratic countries: A crossnational comparison. Local Government Studies 34(2):147-178.

Rau, Krishna. 2007. Artists win in development deal. Xtra!. Online. Accessed 12 February 2012 from http://www.xtra.ca/public/Toronto/Artists_win_in development_deal-3852.aspx.

Sassen, Saskia. 1994. Cities in a World Economy. Thousand Oaks, CA: Pine Forge Press.

Savitch, H.V. and P. Kantor. 2002. Cities in the International Marketplace. Princeton, NJ: Princeton University Press.

Scott, Allen John. 2000. The Cultural Economy of Cities: Essays on the Geography of Image-Producing Industries. Thousand Oaks, CA: Sage. 
Silver, Daniel, Terry Nichols Clark, and Clemente Jesus Navarro Yanez. 2010. Scenes: Social context in an age of contingency. Social Forces 88(5):2293-2324.

Silver, Daniel. 2011. The moodiness of action. Sociological Theory 29(3):199222.

2012. Local politics in the creative city: The case of Toronto. In Carl Grodach and Daniel Silver, eds., The Politics of Urban Cultural Policy, Global Perspectives. London: Routledge.

Smith, Neil. 2002. New globalism, new urbanism: Gentrification as global urban strategy. Antipode 3(3):427-50.

Statistics Canada. Canadian business patterns (1999-2008): establishment counts by Canada and provinces, industry sector (NAICS, 6-digit) [computer file]. Ottawa, Ont.: Statistics Canada. Business Register Division [producer]; Statistics Canada. Data Liberation Initiative [distributor] (accessed April 2009).

Stinchcombe, Arthur L. 1968. Constructing Social Theories. Chicago: University of Chicago Press.

Taylor, Charles. 2007. A Secular Age. Cambridge, MA: Belknap Press of Harvard University Press.

The Theater Loop. 2009. Online. Accessed 12 March 2012 from http://leisureblogs.chicagotribune.com/the theater loop/2009/10/new-nea-chieflauds-daley-arts-policy-says-model-for-nation.html\#at.

Whaley, Karen. 2007. Condo project on Queen West approved. The Torontoist Online. Accessed February 2012from http://torontoist.com/2007/01/ condo project $\mathrm{O} /$.

Zukin, Sharon. 1982. Loft Living: Culture and Capital in Urban Change. Baltimore, MD: Johns Hopkins University Press. 2009. Naked City: The Death and Life of Authentic Urban Places. New York: Oxford University Press.

2010. Naked City: The Death and Life of Authentic Urban Places. New York: Oxford University Press.

Terry Nichols Clark is Professor of Sociology at the University of Chicago. $\mathrm{He}$ holds MA and $\mathrm{PhD}$ degrees from Columbia University, and has taught at Columbia, Harvard, Yale, the Sorbonne, University of Florence, and UCLA. He has published some 30 books. He coordinates the Fiscal Austerity and Urban Innovation Project, surveying 1200 cities in the US and 38 other countries. www. faui.org. He is analyzing neighbourhood cultural scenes as drivers of urban development. http://www.tnc-newsletter.blogspot.com/.

Daniel Silver is Assistant Professor of Sociology at the University of Toronto. He received his $\mathrm{PhD}$ from the Committee on Social Thought at the University of Chicago. His research spans social theory, urban and community sociology, and the sociology of culture. 
